\title{
COUNTERGRADIENT VARIATION IN GROWTH OF BARB (Barbonymus balleroides Val. 1842) DOMESTICATED AT DIFFERENT ALTITUDES
}

\author{
Jojo Subagja"), Vitas Atmadi Prakoso**\#, Otong Zenal Arifin*, and Endang Haris Suhud ${ }^{* *}$ \\ *) Institute for Freshwater Aquaculture Research and Fisheries Extension \\ *I) Institute for Conservation on Inland Open-Water Fisheries and Ornamental Fish, West Java
}

(Received 1 December 2017; Final revised 29 December 2017; Accepted 2 January 2018)

\begin{abstract}
Barb (Barbonymus balleroides Val. 1842) is one of the native species found in many rivers of Asian countries, including Indonesia. This species had higher commercial value compared with other fish species popular among consumers. In terms of supporting its domestication, information regarding the optimal aquaculture system of the fish is needed, one of which is its rearing location. Currently, there is limited information on rearing the fish at different locations with different altitude. This research aimed to obtain the growth of barb fingerlings reared in three locations with different altitudes. The study was conducted in the ponds located at Cijengkol area (ASL $<200 \mathrm{~m}$ ), Maleber $(200 \mathrm{~m}<\mathrm{ASL}<400 \mathrm{~m})$, and Ciherang (ASL $>400 \mathrm{~m})$, West Java. Fingerlings of domesticated barb (total length $4.48 \pm 0.10 \mathrm{~cm}$; weight $0.95 \pm 0.06 \mathrm{~g}$ ) were stocked in three fixed net cages (size $2 \mathrm{~m} \times 2 \mathrm{~m} \times 1 \mathrm{~m}$ ) in a pond $(40 \mathrm{~m} \times 20 \mathrm{~m}$ ) at each location. Fish werefed with commercial feed (30\%protein) of 5\%biomass three times per day during 120 days of rearing. Water quality parameters observed were temperature, dissolved oxygen, and $\mathrm{pH}$. Measured parameters were length gain, weight gain, specific growth rate, average daily growth, biomass gain, feed conversion ratio, and survival rate. The results showed that the fish reared in Maleber showed the best growth and feed conversion ratio compared to other locations $(P<0.05)$. Meanwhile, no significant differences were found on the survival rate within all treatments. The growth of barb fingerlings is more optimal if reared in midland areas which have suitable temperature ranges for their growth.
\end{abstract}

\section{KEYWORDS: Barb fingerlings; Barbonymus balleroides; domestication; growth; altitude}

\section{INTRODUCTION}

In terms of growth rate, altitude is correlated with the thermal gradients in the environment. Meanwhile, thermal gradients itself has significant influences on fish physiology prior to adaptation and maintain their stable conditions, such as metabolic rates and hydrodynamic body forms (Levinton \& Monahan, 1983; Elliott, 1994; Taniguchi \& Nakano, 2000; Jacobsen, 2008; Winemiller et al., 2008). Growth becomes a main parameter related to survival, longevity, and reproduction (Wootton, 1998; Hendry \& Stearns, 2004). Several fish species showed growth variations as a result of their adaptation to different environmental conditions (Elliott, 1994; Nislow, 2000; Nicola \& Almodovar, 2004). A variation on fish growth performance may reflect their temperature adaptation

\footnotetext{
\# Correspondence: Institute for Freshwater Aquaculture Research and Fisheries Extension. Jl. Sempur No.1, Bogor 16129, West Java, Indonesia.

Phone: + 622518313200

E-mail: vitas.atmadi@gmail.com
}

(Conover \& Present, 1990; Conover et al., 1997), with each fish populations displaying faster growth at their optimal temperatures and lower growth at higher or lower temperatures.

Barb (Barbonymus balleroides Val. 1842) is one of the native fish species in Indonesia that exist in many rivers in Java and Kalimantan (Kottelat et al., 1993). The fish population is currently threatened by habitat destruction and overexploitation (Rumondang, 2013). Thus, it is necessary to domesticate this species to support their conservation as well as increase the aquaculture productivity in Indonesia.

According to Balon (2004), domesticated species are generally possessed for particular purposes, such as control their breeding and observed their behaviors, morphological, as well as its physiological variations. Teletchea (2017) suggested that animal domestication is a long and endless process in which animals become more adapted to human and captivity conditions. Based on domestication literature, some species have undergone this process for a long time 
and have reached level-5 for many years or centuries, while other species just had entered it (level-1 or 2).

In the process of domestication, aquaculture activities should be conducted to manage biodiversity and food security. However, information on optimal aquaculture system is required to reach that purpose. Certain fish species are able to adapt and grow well at different temperatures associated with altitude. Observation on growth parameters at different altitudes for barb culture could be important for aquaculture application. Several studies of fish growth in different locations have been conducted, such as in Pangasius (Tahapari et al., 2012), tilapia (Kusmini et al., 2011; Ariyanto \& Listiyowati, 2015; Dereje et al., 2015), African catfish (Iswanto et al., 2015), salmon parr (Baum et al., 2004), turbot (Imsland et al., 2000), and brown trout (Parra et al., 2009). Recently, several studies on barb culture had been conducted for domestication program (Kusmini et al., 2016; Arifin et al., 2017; Radona et al., 2017). However, information on the growth variations of Barbonymus ballaroides at different altitudes has not been widely studied. Therefore, this study aims to determine the variation of fingerlings' growth in three locations with different altitudes.

\section{MATERIALS AND METHODS}

The study was conducted in pond facilities belonged to the Institute for Conservation on Inland Open-Water Fisheries and Ornamental Fish (BP3UIH), West Java, located in Cijengkol, Maleber, and Ciherang (West Java) from September 2016 to February 2017. The selection of test locations was conducted based on the altitude of each pond, where Cijengkol represented the low-altitude ( $<200 \mathrm{~m}$ above sea level), Maleber represented the medium-altitude (between $200 \mathrm{~m}$ and $400 \mathrm{~m}$ above sea level), and Ciherang represented the high-altitude (> $400 \mathrm{~m}$ above sea level) culture environments (Figure 1).

Barb fingerlings (total length: $4.48 \pm 0.10 \mathrm{~cm}$; weight: $0.95 \pm 0.06 \mathrm{~g}$ ) were stocked in three different fixed net cages (size: $2 \mathrm{~m} \times 2 \mathrm{~m} \times 1 \mathrm{~m}$; stocking density: 750 fish/net) placed inside a $40 \mathrm{~m} \times 20 \mathrm{~m}$ pond at each location. Fish were fed with commercial feed (30\% protein) of $10 \%$ biomass per day with feeding frequency of three times per day. Data collections (length and weight measurements) were performed using random sampling from $30 \%$ of the total fish in each treatment and replication once in every 30 days during 120 days of the study period. Furthermore, length gain $(\Delta L)$, weight gain $(\Delta W)$, specific growth rate (SGR), average daily growth (ADG), food conversion ratio (FCR), and survival rate (SR) were calculated at the end of the rearing period. All of the growth parameters were calculated following the equations suggested by Effendie (2002) follows:

$$
\begin{aligned}
& \Delta \mathrm{L}=\mathrm{L}_{\mathrm{t}}-\mathrm{L}_{0} \\
& \Delta \mathrm{W}=\mathrm{W}_{\mathrm{t}}-\mathrm{W}_{0} \\
& \mathrm{SGR}=\left\{\frac{\left(\ln \mathrm{W}_{\mathrm{t}}-\ln \mathrm{W}_{0}\right)}{\mathrm{t}}\right\} \times 100 \% \\
& \mathrm{ADG}=\frac{\left(\mathrm{W}_{\mathrm{t}}-\mathrm{W}_{0}\right)}{\mathrm{t}} \\
& \mathrm{FCR}=\frac{\mathrm{F}}{\left(\mathrm{W}_{\mathrm{t}}-\mathrm{W}_{0}\right)} \\
& \mathrm{SR}=\frac{\mathrm{N}_{\mathrm{t}}}{\mathrm{N}_{0}} \times 100 \%
\end{aligned}
$$

Where $L_{t}$ represents the final length, $L_{0}$ is the initial length, $W_{t}$ is the final weight, $W_{0}$ is the initial weight, $t$ is the duration of the study. $F$ is the total amount of feed given during the study (day), $N_{t}$ is the final number of fish, $\mathrm{N}_{0}$ is the initial number of fish.

Measured water quality parameters in the study included temperature and dissolved oxygen measured using dissolved oxygen meter (Trans Instrument HD3030), and $\mathrm{pH}$ measured using $\mathrm{pH}$ meter (Trans Instrument Senz pH Pro). Collected data were tested statistically using one-way analysis of variance (ANOVA).

\section{RESULTS AND DISCUSSION}

The results of water quality observations at each location indicated that water quality parameters (temperature, dissolved oxygen, and $\mathrm{pH}$ ) were still within the normal ranges for barb. However, the water temperature showed significant differences between locations, with the highest found at Cijengkol and lowest found at Ciherang (Table 1). The optimum growth of domesticated barb was found at Maleber with an altitude of 200-400 m above sea level (Table 2). The growth parameter at Maleber differed significantly compared to the other locations (Cijengkol and Ciherang) $(P<0.05)$.

This result is also in accordance with a statement from Weatherley \& Gill (1987) which stated that water quality is a variable that greatly affects the survival rate, reproduction, growth, management, and fish production. Temperature and dissolved oxygen 


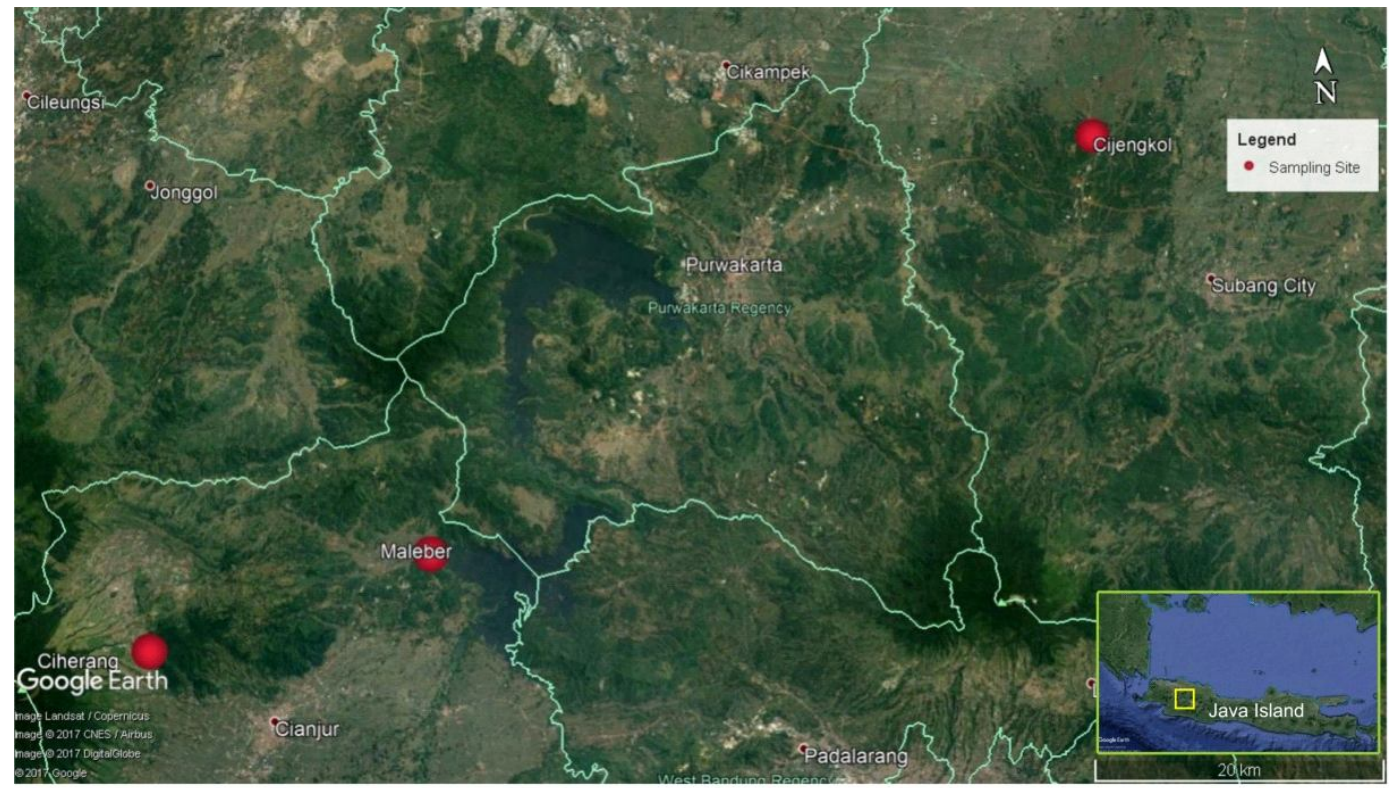

Figure 1. Map of rearing locations in this study.

Table 1. Water quality on rearing media of domesticated barb fingerlings (Barbonymus balleroides) reared on different altitude locations for 120 days

\begin{tabular}{|c|c|c|c|}
\hline \multirow[b]{2}{*}{ Parameters } & \multicolumn{3}{|c|}{ Altitude of rearing locations } \\
\hline & $\begin{array}{c}\text { Cijengkol } \\
(\text { ASL }<200 \mathrm{~m})\end{array}$ & $\begin{array}{c}\text { Maleber } \\
(200 \mathrm{~m}<\mathrm{ASL}<400 \mathrm{~m})\end{array}$ & $\begin{array}{c}\text { Ciherang } \\
\text { (ASL > } 400 \mathrm{~m} \text { ) }\end{array}$ \\
\hline Water temperature $\left({ }^{\circ} \mathrm{C}\right)$ & $28.15 \pm 0.49^{c}$ & $25.80 \pm 0.85^{b}$ & $23.75 \pm 0.64^{\mathrm{a}}$ \\
\hline Dissolved oxygen (mg/L) & $4.75 \pm 0.78^{\mathrm{a}}$ & $4.80 \pm 0.57^{\mathrm{a}}$ & $4.35 \pm 0.78^{\mathrm{a}}$ \\
\hline pH & $7.7 \pm 0.3^{\mathrm{a}}$ & $7.2 \pm 0.6^{\mathrm{a}}$ & $7.8 \pm 0.2^{a}$ \\
\hline
\end{tabular}

Table 2. Growth of domesticated barb (Barbonymus balleroides) reared on different altitude locations for 120 days

\begin{tabular}{lccc}
\hline & \multicolumn{3}{c}{ Altitude of rearing locations } \\
\cline { 2 - 4 } \multicolumn{1}{c}{ Parameters } & $\begin{array}{c}\text { Cijengkol } \\
\text { (ASL }<\mathbf{2 0 0} \mathbf{~ m ) ~}\end{array}$ & $\begin{array}{c}\text { Maleber } \\
(\mathbf{2 0 0} \mathbf{~}<\mathbf{A S L}<\mathbf{4 0 0} \mathbf{~ m})\end{array}$ & $\begin{array}{c}\text { Ciherang } \\
\text { (ASL }>\mathbf{4 0 0} \mathbf{~ m})\end{array}$ \\
\hline Initial length (cm) & $4.51 \pm 0.16^{\mathrm{a}}$ & $4.50 \pm 0.05^{\mathrm{a}}$ & $4.45 \pm 0.11^{\mathrm{a}}$ \\
Final length (cm) & $8.54 \pm 0.29^{\mathrm{c}}$ & $10.77 \pm 0.41^{\mathrm{a}}$ & $9.94 \pm 0.20^{\mathrm{b}}$ \\
Length gain (cm) & $4.03 \pm 0.44^{\mathrm{c}}$ & $6.27 \pm 0.45^{\mathrm{a}}$ & $5.49 \pm 0.15^{\mathrm{b}}$ \\
Initial weight (g) & $1.00 \pm 0.07^{\mathrm{a}}$ & $0.90 \pm 0.03^{\mathrm{a}}$ & $0.94 \pm 0.05^{\mathrm{a}}$ \\
Final weight (g) & $6.98 \pm 1.27^{\mathrm{c}}$ & $13.32 \pm 1.61^{\mathrm{a}}$ & $9.80 \pm 1.04^{\mathrm{b}}$ \\
Weight gain (g) & $5.98 \pm 1.35^{\mathrm{c}}$ & $12.42 \pm 1.62^{\mathrm{a}}$ & $8.86 \pm 1.04^{\mathrm{b}}$ \\
Specific growth rate (\%/day) & $1.61 \pm 0.22^{\mathrm{c}}$ & $2.24 \pm 0.12^{\mathrm{a}}$ & $1.95 \pm 0.11^{\mathrm{b}}$ \\
Average daily growth (g/day) & $0.050 \pm 0.011^{\mathrm{c}}$ & $0.103 \pm 0.014^{\mathrm{a}}$ & $0.074 \pm 0.009^{\mathrm{b}}$ \\
\hline
\end{tabular}

ASL : Above Sea Level

Description : Different superscript letters indicated significant differences between treatments $(P<0.05)$ 
are the most important parameters in aquaculture systems. The optimum dissolved oxygen could increase growth and feed conversion ratio (Mallya, 2007).

Based on this research, the optimal condition for the growth of barb fingerling is in the midland areas. Different altitudes associated with water quality parameters affect the growth of fish. In this case, the temperature became limiting factors on the growth of barb, as reported by Weatherley \& Gill (1987). These temperature differences would influence the food consumption, digestibility, and growth of fish through metabolic variation (Van Dam \& Pauly, 1995; Gillooly et al., 2001), use of nutrients and energy (Azevedo et al., 1998; Buentello et al., 2000), as well as the activity of digestive enzymes (Ahmad et al., 2014). Temperature influence on fish growth has also been widely reported in several previous studies with different fish species (Jobling, 1993; Szczepkowski et al., 2006; Taufik et al., 2009; Wu et al., 2015). In the optimal temperature conditions, their metabolism and appetite will be optimum. Thus, it will have a positive effect on fish growth (Edwards et al., 1979; Kusakabe et al., 2017).

Another parameter measured in this study was feed conversion ratio. The value at Maleber (3.69 \pm 0.01 ) was significantly lower than those of Cijengkol $(6.08 \pm 0.73)$ and Ciherang $(5.96 \pm 0.13)(P<0.05)$. However, there was no significant difference between locations in terms of survival rate $(P>0.05)$ (Table 3 ).

In this study, feed conversion ratio of barb in Maleber was lower than those of Cijengkol and Ciherang $(P<0.05)$ because the midland location (Maleber) is more optimal for the growth of barb. Feed conversion ratio is the indicator to measure the effectiveness of feeding and feed quality used (Millamena et al., 2002). This result is consistent with the results of the Arnasson et al. (2009) which stated that maintenance of fish with optimal conditions and feeding techniques will result in better a feed conversion ratio. Furthermore, in terms of water temperature, several previous studies also revealed that an optimal rearing temperature affected feed conversion ratio of several fish species, such as turbot (Van Ham et al., 2003), Atlantic salmon (Handeland et al., 2008), cod (Bjornsson et al., 2001), and channel catfish (Buentello et al., 2000). Water temperature generally affected metabolic energy demands. Thus, the feeding rates are typically adjusted to meet the fish demands (Van Dam \& Pauly, 1995).

\section{CONCLUSION}

The optimal location for the growth of barb (Barbonymus balleroides) is in midland areas ( $200 \mathrm{~m}<$ ASL $<400 \mathrm{~m}$ ), because the water temperature in midland areas is relatively comfortable for barb compared to lowland or highland areas.

\section{ACKNOWLEDGEMENTS}

The research is part of the cooperation between the Institute for Freshwater Aquaculture Research and Fisheries Extension (BRPBATPP) and Institute for Conservation on Inland Open-Water Fisheries and Ornamental Fish, West Java (BP3UIH) funded by DPA2016 BPPPUIH Ciherang-Department of Marine and Fisheries of West Java Province. The authors wish to thank all the staff of BP3UIH Ciherang, Department of Marine Affairs and Fisheries of West Java Province for their contribution in this research.

\section{REFERENCES}

Ahmad, T., Singh, S.P., Khangembam, B.K., Sharma, J.G., \& Chakrabarti, R. (2014). Food consumption and digestive enzyme activity of Clarias batrachus exposed to various temperatures. Aquaculture Nutrition, 20(3), 265-272.

Arifin, 0.Z., Subagja, J., Prakoso, V.A., \& Suhud, E.H. (2017). Effect of stocking density on growth performance of domesticated barb (Barbonymus

Table 3. Feed conversion ratio and survival rate of domesticated barb fingerlings (Barbonymus balleroides) reared on different altitude locations for 120 days

\begin{tabular}{lccc}
\hline \multirow{2}{*}{ Parameters } & \multicolumn{3}{c}{ Altitude of rearing locations } \\
\cline { 2 - 4 } & $\begin{array}{c}\text { Cijengkol } \\
\text { (ASL }<\mathbf{2 0 0} \mathbf{~ m})\end{array}$ & $\begin{array}{c}\text { Maleber } \\
(\mathbf{2 0 0} \mathbf{~}<\text { ASL }<\mathbf{4 0 0} \mathbf{~ m})\end{array}$ & $\begin{array}{c}\text { Ciherang } \\
\text { (ASL }>\mathbf{4 0 0} \mathbf{~ m})\end{array}$ \\
\hline Feed conversion ratio & $6.08 \pm 0.73^{\mathrm{b}}$ & $3.69 \pm 0.01^{\mathrm{a}}$ & $5.96 \pm 0.13^{\mathrm{b}}$ \\
Survival rate (\%) & $93.02 \pm 5.97^{\mathrm{a}}$ & $96.00 \pm 4.29^{\mathrm{a}}$ & $98.56 \pm 2.50^{\mathrm{a}}$ \\
\hline ASL & : Above Sea Level & & \\
Description & : Different superscript letters indicated significant differences between treatments $\mathrm{P}<0.05$ )
\end{tabular}


balleroides). Indonesian Aquaculture Journal, 12(1), 1-6.

Ariyanto, D., \& Listiyowati, N. (2015). Genotype by environment interaction, phenotypic adaptability and stability of four varieties of tilapia (Oreochromis niloticus). Jurnal Riset Akuakultur, 10(1), 1-9.

Arnasson, T., Björnsson, B., Steinarsson, A., \& Oddgeirsson, M. (2009). Effects of temperature and body weight on growth rate and feed conversion ratio in turbot (Scophthalmus maximus). Aquaculture, 295(3), 218-225.

Azevedo, P.A., Cho, C.Y., Leeson, S., \& Bureau, D.P. (1998). Effects of feeding level and water temperature on growth, nutrient and energy utilization and waste outputs of rainbow trout (Oncorhynchus mykiss). Aquatic Living Resources, 11(4), 227-238.

Balon, E.K. (2004). About the oldest domesticates among fishes. Journal of Fish Biology, 65(s1), 1-27.

Baum, D., Laughton, R., Armstrong, J.D., \& Metcalfe, N.B. (2004). Altitudinal variation in the relationship between growth and maturation rate in salmon parr. Journal of Animal Ecology, 73(2), 253260.

Björnsson, B., Steinarsson, A., \& Oddgeirsson, M. (2001). Optimal temperature for growth and feed conversion of immature cod (Gadus morhua L.). ICES Journal of Marine Science, 58(1), 29-38.

Buentello, J.A., Gatlin, D.M., \& Neill, W.H. (2000). Effects of water temperature and dissolved oxygen on daily feed consumption, feed utilization and growth of channel catfish (Ictalurus punctatus). Aquaculture, 182(3), 339-352.

Conover, D.O., \& Present, T.M.C. (1990). Countergradient variation in growth rate: compensation for length of the growing season among Atlantic silversides from different latitudes. Oecologia, 83(3), 316-324.

Conover, D.O., Brown, J.J., \& Ehtisham, A. (1997). Countergradient variation in growth of young striped bass (Morone saxatilis) from different latitudes. Canadian Journal of Fisheries and Aquatic Sciences, 54(10), 2401-2409.

Dereje, D., Devi, L.P., Sreenivasa, V., \& Abebe, G. (2015). The growth performance of Nile tilapia in earthen ponds located at different altitudes of Toke Kutaye Woreda, Ethiopia. International Journal of Aquaculture, 5(35), 1-7.

Edwards, R.W., Densem, J.W., \& Russell, P.A. (1979). An assessment of the importance of temperature as a factor controlling the growth rate of brown trout in streams. The Journal of Animal Ecology, p. 501-507.
Effendie, M.I. (2002). Fisheries biology. Yogyakarta: Yayasan Pustaka Nusatama, 163 pp.

Elliott, J.M. (1994). Quantitative ecology and the brown trout. New York: Oxford: Oxford University Press, 286 pp.

Gillooly, J.F., Brown, J.H., West, G.B., Savage, V.M., \& Charnov, E.L. (2001). Effects of size and temperature on metabolic rate. Science, 293(5538), 22482251.

Handeland, S.O., Imsland, A.K., \& Stefansson, S.O. (2008). The effect of temperature and fish size on growth, feed intake, food conversion efficiency and stomach evacuation rate of Atlantic salmon post-smolts. Aquaculture, 283(1), 36-42.

Hendry, A.P., \& Stearns, S.C. (2004). Evolution Illuminated: Salmon and Their Relatives. New York: Oxford: Oxford University Press, $510 \mathrm{pp}$.

Imsland, A.K., Foss, A., Névdal, G., Cross, T., Bonga, S.W., Ham, E.A., \& Stefansson, S.O. (2000). Countergradient variation in growth and food conversion efficiency of juvenile turbot. Journal of Fish Biology, 57(5), 1213-1226.

Iswanto, B., Suprapto, R., Marnis, H., \& Imron. (2015). Performance test of magnifation field on catfish seed (Clarias gariepinus) fast growing third generation. In Sugama, K., Kristanto, A.H., Radiarta, I N., Lusiastuti, A.M., Kusdiarti, Priono, B., Insan, I., Dewi, R.R.S.P.S., \& Gardenia, L. (Eds.). Prosiding Forum Inovasi Teknologi Akuakultur 2015 (p. 95-101). Jakarta: Pusat Penelitian dan Pengembangan Perikanan Budidaya.

Jacobsen, D. (2008). Tropical high-altitude streams. In Tropical stream ecology (Dudgeon, D. (Ed.). London: Academic Press, p. 219-256.

Jobling, M. (1993). Bioenergetics: feed intake and energy partitioning. In Rankin, J.C., \& Jensen, F.B. (Eds.). Fish ecophysiology. London: Chapman \& Hall, p. 1-44.

Kottelat, M., Whitten, A.J., Kartikasari, S.N., \& Wirjoatmodjo, S. (1993). Freshwater fishes of Western Indonesia and Sulawesi. Hong Kong: Periplus Editions, 221 pp.

Kusakabe, K., Hata, M., Shoji, J., Hori, M., \& Tomiyama, T. (2017). Effects of water temperature on feeding and growth of juvenile marbled flounder Pseudopleuronectes yokohamae under labo ratory conditions: evaluation by group-and individual-based methods. Fisheries Science, 83(2), 215219.

Kusmini, I.I., Gustiano, R., Prihadi, T.H., \& Huwoyon, G.H. (2011). The growth and production of BEST tilapia in several centers of cultivation in IndonsiaK. In Haryanti, Rachmansyah, Sugama, K., 
Parenrengi, A., Sudradjat, A., Imron, Sunarto, A., Sumiarsa, G.S., Azwar, Z.I., \& Kristanto, A.H. (Eds.). Prosiding Forum Inovasi Teknologi Akuakultur 2011 (p. 459-468). Jakarta: Pusat Penelitian dan Pengembangan Perikanan Budidaya.

Kusmini, I.I., Putri, F.P., \& Prakoso, V.A. (2016). Reproductive biology and length-weight relationship on fecundity of lalawak (Barbonymus balleroides). Jurnal Riset Akuakultur, 11(4), 339-345 (in Indonesian with English abstract).

Levinton, J.S., \& Monahan, R.K. (1983). The latitudinal compensation hypothesis: Growth data and a model of latitudinal growth differentiation based upon energy budgets. II. Intraspecific comparisons between subspecies of Ophryotrocha puerilis (polychaeta: Dorvilleidae). The Biological Bulletin, 165(3), 686-698, doi: 10.2307/1541472.

Mallya, Y.J. (2007). The effects of dissolved oxygen on fish growth in aquaculture. The United Nations University fisheries training programmer, Final project, $30 \mathrm{pp}$.

Millamena, O.M., Coloso, R.M., \& Pascual, F. (2002). Nutrition in tropical aquaculture-essentials of fish nutrition, feeds and feeding of tropical aquatic species. Southeast Asian Fisheries Development Center. Aquaculture Department. Tigbauan, Iloilo Philippines, 280 pp.

Nicola, G.G., \& Almodovar, A. (2004). Growth pattern of stream-dwelling brown trout under contrasting thermal conditions. Transactions of the American Fisheries Society, 133(1), 66-78.

Nislow, K.H. (2000). Symposium review: International symposium on the implications of salmonid growth variation. Reviews in Fish Biology and Fisheries, 10(4), 521-527.

Parra, I., Almodóvar, A., Nicola, G.G., \& Elvira, B. (2009). Latitudinal and altitudinal growth patterns of brown trout Salmo trutta at different spatial scales. Journal of Fish Biology, 74(10), 2355-2373.

Radona, D., Prakoso, V.A., \& Kusmini, I.I. (2017). Analysis of growth of lalawak Barbonymus balleroides (Valenciennes, 1842) in three culture methods. Indonesian Aquaculture Journal, 12(1), 1520.

Rumondang. (2013). The study of food habit and growth of lalawak (Barbonymus balleroides Val. 1842) in Serayu River, Banjarnegara, Central Java. Thesis. Bogor Agricultural University. Bogor, 61 pp (in Indonesian with English abstract).

Szczepkowski, M., Szczepkowska, B., \& Krzywosz, T. (2006). The impact of water temperature on selected rearing indices of juvenile whitefish
(Coregonus lavaretus (L.)) in a recirculating system. Archives of Polish Fisheries (Poland), 14, 95-104.

Tahapari, E., Sularto, \& Nurlaela, I. (2012). Multilocation test of nasutus hybrid catfish (crossing catfish female with nasutus hybrid male) in various cultivatedecosystem. In Haryanti, Rachmansyah, Sugama, K., Parenrengi, A., Sudradjat, A., Imron, Sunarto, A., Sumiarsa, G.S., Azwar, Z.I., \& Kristanto, A.H. (Eds.). Prosiding Forum Inovasi Teknologi Akuakultur 2012 (p. 10451052). Jakarta: Pusat Penelitian dan Pengembangan Perikanan Budidaya.

Taniguchi, Y., \& Nakano, S. (2000). Condition-specific competition: implications for the altitudinal distribution of stream fishes. Ecology, 81(7), 20272039, doi: 10.1890/0012-9658.

Taufik, I., Azwar, Z.I., \& Sutrisno. (2009). Effect of water temperature on fingerling of sand goby (Oxyeleotris marmorata, Blkr.) reared in recirculation system tanks. Jurnal Riset Akuakultur, 4(3), 319325.

Teletchea, F. (2017). Wildlife conservation: Is domestication a solution?. Global Exposition of Wildlife Management, Dr. Gbolagade Akeem Lameed (Ed.), InTech, doi: 10.5772/65660. Available from: https:/ /www.intechopen.com/books/global-expositionof-wild life-management/wildlife-conservation-isdomestication-a-solution-.

Van Dam, A.A., \& Pauly, D. (1995). Simulation of the effects of oxygen on food consumption and growth of Nile tilapia, Oreochromis niloticus L. Aquaculture Research, 26, 427-440.

Van Ham, E.H., Berntssen, M.H., Imsland, A.K., Parpoura, A.C., Bonga, S.E.W., \& Stefansson, S.O. (2003). The influence of temperature and ration on growth, feed conversion, body composition and nutrient retention of juvenile turbot (Scophthalmus maximus). Aquaculture, 217(1), 547558.

Weatherley, A.H., \& Gill, H.S. (1987). The biology of fish growth. London: Academic Press, 443 pp.

Winemiller, K.O., Agostinho, A.A., \& PellegriniCarasmachi, E. (2008). Fish ecology in tropical streams. In Tropical stream ecology. Dudgeon, D. (Ed.), London: Academic Press, p. 107-146.

Wootton, R. (1998). Ecology of teleost fishes. London: Chapman \& Hall, 386 pp.

Wu, B., Luo, S., \& Wang, J. (2015). Effects of temperature and feeding frequency on ingestion and growth for rare minnow. Physiology \& Behavior, 140, 197-202. 